\title{
Article \\ The Impact of Protease during Recovery from Viable but Non-Culturable (VBNC) State in Vibrio cholerae
}

\author{
Anusuya Debnath * and Shin-ichi Miyoshi
}

check for updates

Citation: Debnath, A.; Miyoshi, S.-i. The Impact of Protease during Recovery from Viable but Non-Culturable (VBNC) State in Vibrio cholerae. Microorganisms 2021, 9, 2618. https://doi.org/10.3390/ microorganisms 9122618

Academic Editor: Matthias Noll

Received: 10 November 2021 Accepted: 15 December 2021 Published: 18 December 2021

Publisher's Note: MDPI stays neutral with regard to jurisdictional claims in published maps and institutional affiliations.

Copyright: (c) 2021 by the authors. Licensee MDPI, Basel, Switzerland. This article is an open access article distributed under the terms and conditions of the Creative Commons Attribution (CC BY) license (https:// creativecommons.org/licenses/by/ $4.0 /)$.
Graduate School of Medicine, Dentistry and Pharmaceutical Sciences, Okayama University, 1-1-1, Tsushimanaka, Kita-ku, Okayama 700-8530, Japan; miyos-s@okayama-u.ac.jp

* Correspondence: anusuyadebnath@yahoo.co.in

\begin{abstract}
Vibrio cholerae can survive cold stress by entering into a viable but non-culturable (VBNC) state, and resuscitation can be induced either by temperature upshift only or the addition of an anti-dormancy stimulant such as resuscitation-promoting factors (Rpfs) at suitable temperature. In this study, the role of proteinase $\mathrm{K}$ was analyzed as an Rpf in $V$. cholerae. A VBNC state was induced in $V$. cholerae AN59 in artificial seawater (ASW) media at $4{ }^{\circ} \mathrm{C}$, and recovery could be achieved in filtered VBNC microcosm, called spent ASW media, merely by a temperature upshift to $37^{\circ} \mathrm{C}$. The resuscitation ability of spent ASW was further enhanced by the addition of proteinase $\mathrm{K}$. The mode of action of proteinase $\mathrm{K}$ was investigated by comparing its effect on the growth of the VBNC and culturable state of $V$. cholerae in ASW and spent ASW media. The presence of proteinase K allowed culturable cells to grow faster in ASW by reducing the generation time. However, this effect of proteinase K was more pronounced in stressed VBNC cells. Moreover, proteinase K-supplemented spent ASW could also accelerate the transition of VBNC into recovered cells followed by rapid growth. Additionally, we found that dead bacterial cells were the substrate on which proteinase $\mathrm{K}$ acts to support high growth in spent ASW. So, the conclusion is that the proteinase K could efficiently promote the recovery and growth of dormant VBNC cells at higher temperatures by decreasing the duration of the initial lag phase required for transitioning from the VBNC to recovery state and increasing the growth rate of these recovered cells.
\end{abstract}

Keywords: VBNC; recovery; proteinase K; growth; protease

\section{Introduction}

The viable but non-culturable state is a distinctive survival strategy adopted by numerous microbial species to habituate in unfavorable environmental conditions. The inability to detect various pathogenic bacteria in the VBNC state makes them a serious threat for food safety and public health because there is always a possibility of their resuscitation under appropriate conditions. Vibrio species are the predominant inhabitants of the marine ecosystem, and several of them were reported to be able to convert into the VBNC state when kept under low temperature and nutrient starvation conditions [1]. Interestingly, some species of Vibrio such as Vibrio splendidus prefer lower winter temperatures than other species [2]. It has been reported that the mere transfer from low temperature to high temperature could induce recovery in Vibrio cholerae, V. parahaemolyticus and V. vulnificus [3-6]. However, recovery from the VBNC state has been addressed different hypotheses; for example, according to Nilsson et al. and Whitesides et al., all the population of $V$. vulnificus in a microcosm become VBNC and resuscitate without cell division. In the case of $V$. cholerae, Ravel et al. supported the concept that the recovered population resulted from the growth of culturable cells, but some studies suggest that few VBNC cells retain their ability to grow and imitate the resuscitation of an entire population [3,7].

Apart from high temperature-induced resuscitation, several other methods were discovered for recovery from the VBNC state. The pathogenic strain of Escherichia coli O157:H7 can be recovered using the autoinducer AI-2 produced during biofilm formation in 
a serum-based media [8]. The resuscitation in E. coli can also be supported by a concoction of amino acids such as methionine, glutamine, threonine, serine and asparagine [9]. In Salmonella enteritidis, it has been shown that sodium pyruvate could restore the biosynthesis of DNA and protein in VBNC cells [10]. Catalase was shown to be a catalyst for resuscitation in S. enterica serovar Typhi [11], S. enteritidis [12] and Vibrio cholerae [13]. Few studies have shown that direct interaction with eukaryotic cells can also facilitate resuscitation. Senoh et al. found that low temperature-induced VBNC cells of different enteric pathogenic species could be converted to the culturable state by co-culture with several eukaryotic cell lines [14]. The inoculation of VBNC cells into an embryonated egg was shown to be an efficient method to recover from the dormant state in Listeria monocytogenes [15] and Campylobacter jejuni [16].

Another class of secretory molecule, a bacterial cytokine known as resuscitationpromoting factor (Rpf), was identified that stimulates resuscitation and growth in Micrococcus luteus and Mycobacterium spp. $[17,18]$. Rpfs of Gram-positive bacteria possess a muralytic activity that is predicted to be responsible for the hydrolysis of peptidoglycan and cell division $[16,17]$. The Rpfs of Gram-negative bacteria known as YaeZ belong to a different class of protein and are essential for both survival and exit from the VBNC condition, as reported for S. enterica serovar Oranienburg and E. coli $[19,20]$. YaeZ of V. parahaemolyticus is reported to be a classic actin-like nucleotide binding protein and essential for recoveryfrom the VBNC state [21].A recent report on Rpf of Vibrio harveyi revealed that the resuscitation-inducing ability of YaeZ was dependent on its proteolytic activity and independent of muralytic activity [22].

It was shown in Staphylococcus aureus that the protease treatment of spent culture supernatant could reduce its resuscitation effect [23], whereas a protease was shown to be an Rpf in $V$. harveyi [22]. In contrast, Pinto et al. suggested that the breakdown products of Rpf obtained by proteinase $\mathrm{K}$ treatment of spent culture supernatant could also restore VBNC cells of E. coli [9]. So, the role of proteinase K as a potential Rpf and its probable mode of action was analyzed in this study. The outcome of this study might be beneficial for the detection of VBNC cells.

\section{Materials and Methods}

\subsection{Bacterial Strains and Growth Conditions}

In this study, $V$. cholerae non-O1/non-O139 strain AN59 isolated from a brackish environment in Okayama was used [3]. Bacteria were grown in Luria-Bertani (LB) broth ( $1 \%$ tryptone, $0.5 \%$ yeast extract and $1 \% \mathrm{NaCl}$ ) at $37^{\circ} \mathrm{C}$ for $18 \mathrm{~h}$, and the culturable cell count was estimated by plating on nutrient agar (NA) plates (BD Difco, Franklin Lakes, NJ, USA).

\subsection{Viable but Non Culturable (VBNC) State}

To experimentally induce the VBNC state, the late-log phase bacterial culture was 100 -fold diluted in $30 \mathrm{~mL}$ ASW media in multiple sets and incubated at $4{ }^{\circ} \mathrm{C}$ [24]. The culturable cell count was determined at an interval of 7days by plating $0.1 \mathrm{~mL}$ of the suspension on NA plates. A the time point at which $0.1 \mathrm{~mL}$ gave no culturable cell count on the NA plate, $10 \mathrm{~mL}$ of the VBNC sample was used instead of $0.1 \mathrm{~mL}$. The $10 \mathrm{~mL}$ VBNC microcosm was filtered through $0.22 \mu \mathrm{m}$ membrane filters (Millipore, Burlington, MA, USA), and the filter was placed on the NA plate for $32 \mathrm{~h}$ at $37^{\circ} \mathrm{C}$. When the culturable cell count became $\leq 1 \mathrm{cfu} \mathrm{mL} \mathrm{m}^{-1}$, it was considered to represent the VBNC state [25].

\subsection{Recovery State}

After entry into the VBNC state, a $10 \mathrm{~mL}$ aliquot of VBNC cells from the $30 \mathrm{~mL}$ VBNC microcosm was shifted from $4{ }^{\circ} \mathrm{C}$ to $37^{\circ} \mathrm{C}$ for recovery on days $1,7,14$ and 21 to check the length of the recovery period. It was kept at $37^{\circ} \mathrm{C}$ in a stationary position, and the recovered cell count ( $\mathrm{cfu} \mathrm{mL}{ }^{-1}$ ) was determined. Simultaneously, another $10 \mathrm{~mL}$ 
aliquot was used to determine the culturable cell count of the VBNC microcosm at these time points.

The spent ASW media was obtained from the original VBNC microcosm by filtration through a $0.22 \mu \mathrm{m}$ membrane filter. The presence and nature of resuscitation-promoting factor (Rpf) in spent ASW media was analyzed by subjecting it to heat and protease treatment. Nine milliliters of spent ASW media was used for heat treatment at $100{ }^{\circ} \mathrm{C}$ for $10 \mathrm{~min}$ and then inoculated with $1 \mathrm{ml}$ of VBNC cells; i.e., 10-fold diluted VBNC cells. For the induction of recovery, this $10 \mathrm{~mL}$ culture was incubated at $37^{\circ} \mathrm{C}$ for $32 \mathrm{~h}$. In another set, $100 \mu \mathrm{g} \mathrm{ml}^{-1}$ proteinase $\mathrm{K}$ was added into $9 \mathrm{~mL}$ of spent ASW media, inoculated with $1 \mathrm{~mL}$ of VBNC cells and incubated at $37^{\circ} \mathrm{C}$ for $32 \mathrm{~h}$. After incubation, the recovered cell count was determined using the plate count method. In some recovery experiments, trypsin and subtilisin A were used. The term "protease" was used for serine protease in general.

\subsection{Culturable State}

The late-log phase bacterial culture was 100-fold diluted in $30 \mathrm{~mL}$ ASW media and incubated at $37^{\circ} \mathrm{C}$ for $16 \mathrm{~h}$ to acclimatize in ASW. On the next day, it was $10^{5}$-fold diluted, and $1 \mathrm{~mL}$ of culturable cells was added to $9 \mathrm{~mL}$ of suitable media so that the final cell concentration would become $10 \mathrm{cfu} \mathrm{mL}^{-1}$.

\subsection{Dead Cell Preparation}

In total, $100 \mu \mathrm{L}\left(10^{7} \mathrm{cfu}\right)$ of late-log phase culture was centrifuged and washed, and the pellet was dissolved in $100 \mu \mathrm{L}$ of $2.5 \mathrm{M} \mathrm{NaCl}$ and incubated at $37^{\circ} \mathrm{C}$ for $2 \mathrm{~h}$, which led to the complete killing of $V$. cholerae, as checked by the plating method. Then, $100 \mu \mathrm{L}$ of dead cell was added into ASW media, which increased the $\mathrm{NaCl}$ molarity from $423 \mathrm{mM}$ to $448 \mathrm{mM}$ in the final volume of $10 \mathrm{~mL}$. This change in molarity did not affect the growth or viability of $V$. cholerae in ASW.

\subsection{Growth in ASW and Spent ASW Media}

The growth of culturable cells and VBNC cells was checked in $10 \mathrm{~mL}$ of different types of media such as ASW, spent ASW, ASW supplemented with proteinase K and spent ASW supplemented with proteinase K. An initial inoculum of $10 \mathrm{cfu} \mathrm{mL}^{-1}$ was used for culturable cells and 0.08 to $<0.01 \mathrm{cfu} \mathrm{mL}^{-1}$ for VBNC cells. After inoculation, the culture was kept at $37^{\circ} \mathrm{C}$ for up to $32 \mathrm{~h}$ in a stationary position, and the cell count was checked at $0 \mathrm{~h}$ and $32 \mathrm{~h}$ time points or at different time points by plating the appropriate dilution on NA plates.

\subsection{RNA Isolation and Real Time RT-PCR}

For quantitative real-time reverse transcription polymerase chain reaction (qRT-PCR) experiments, the RNA was isolated from culturable and recovery states of $V$. cholerae cells. Since, RNA was purified at $2 \mathrm{~h}, 4 \mathrm{~h}$ and $8 \mathrm{~h}$ after recovery induction, there was no visible pellet. Therefore, the sample was filtered through a $0.22 \mu \mathrm{m}$ membrane filter to collect the cells, and RNA was extracted as mentioned previously [3]. For RT-PCR, we used aLuna ${ }^{\circledR}$ Universal One-Step kit RT-qPCR kit (NEB, Ipswich, MA, USA) with 50 ng of RNA in a Mini Opticon Real-time PCR system (BIO-RAD, Hercules, CA, USA). The relative mRNA expression of the protease genes such as vc0099, vc1200, vca0803 and vc1989 (yaeZ) was calculated using $d n a K$ as an internal control at time points of $2 \mathrm{~h}, 4 \mathrm{~h}$ and $8 \mathrm{~h}$ after the temperature upshift. The list of primers is provided in Table S1.

\subsection{Skim Milk Plate Assay}

Two types of skim milk (Wako Chemicals, Richmond, VA, USA) plate were prepared using ASW and spent ASW media. We added $0.2 \mathrm{~g}$ of skim milk to $10 \mathrm{~mL}$ of $\mathrm{dH}_{2} \mathrm{O}$, and $0.6 \mathrm{~g}$ of agar was added to $30 \mathrm{~mL}$ ASW, followed by heating at $100{ }^{\circ} \mathrm{C}$ for $10 \mathrm{~min}$. These two solutions were then mixed to make a $1 \%$ skim milk ASW plate. Another type of plate was prepared by mixing two sterile solutions consisting of $0.4 \mathrm{~g}$ of skim milk in $10 \mathrm{~mL}$ of 
$\mathrm{dH}_{2} \mathrm{O}$ and $0.6 \mathrm{~g}$ agar in $10 \mathrm{~mL}$ of ASW media. This $20 \mathrm{~mL}$ mixture was cooled down to $50{ }^{\circ} \mathrm{C}$, and then $20 \mathrm{~mL}$ of spent ASW was added, as high temperature could destroy the resuscitation effect of spent ASW. The $40 \mathrm{~mL}$ solution was poured into a Petridish to give $1 \%$ skim milk spent ASW plate. A well was created of $8 \mathrm{~mm}$ in diameter, and $200 \mu \mathrm{L}$ of VBNC sample was loaded followed by incubation at $37^{\circ} \mathrm{C}$ for $96 \mathrm{~h}$.

\subsection{Statistical Analysis}

The data were analyzed by Student's $t$-test. A probability level $(p)$ value of $\leq 0.05$ was taken as statistically significant. The data were represented as means $\pm \mathrm{SE}$ of three independent events.

\section{Results}

3.1. The Effect on Resuscitation Ability of V. cholerae VBNC Cells Either in Heat-Treated or Protease-Supplemented Spent ASW

The $V$. cholerae strain AN59 took 56 days to enter the VBNC state when incubated at $4{ }^{\circ} \mathrm{C}$ under nutrient starvation conditions in ASW. It showed a gradual decrease in culturability from $4.2 \times 10^{7} \mathrm{cfu} \mathrm{mL} \mathrm{mL}^{-1}$ to $\leq 1 \mathrm{cfu} \mathrm{mL}^{-1}$ (Figure 1a). The stable mRNA expression of groEL and $d n a K$ throughout the VBNC induction period was used as an indicator of viability for VBNC cells (Figure 1b). After entry into the VBNC state, the recovery was observed for a period of two weeks (between days 56 to 70) by a temperature upshift from $4{ }^{\circ} \mathrm{C}$ to $37^{\circ} \mathrm{C}$. After overnight recovery at elevated temperature, the recovered cell count was approximately $6 \times 10^{6} \mathrm{cfu} \mathrm{mL}^{-1}$.

(a)

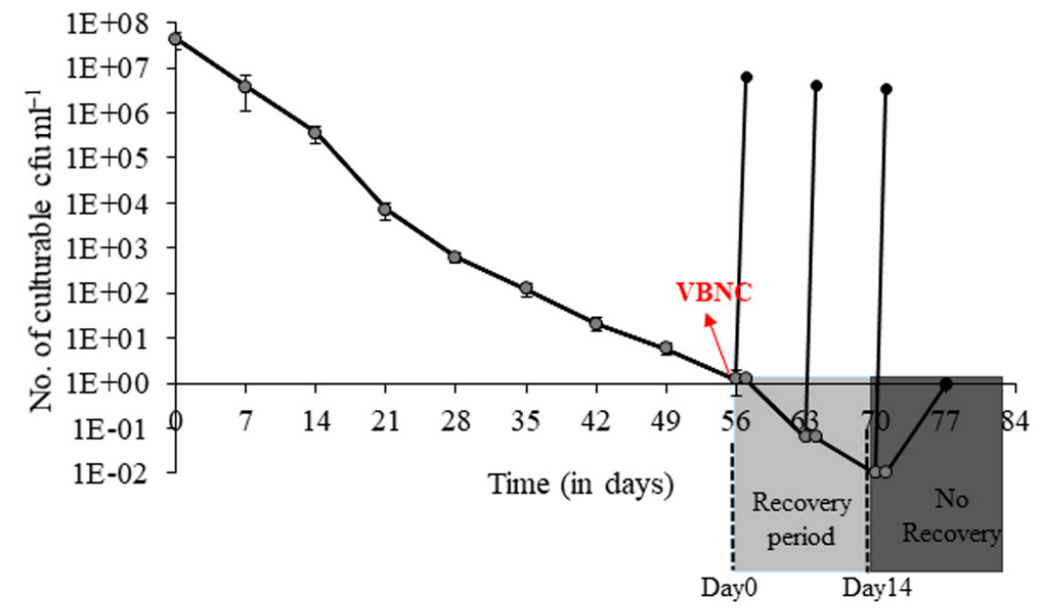

(b)

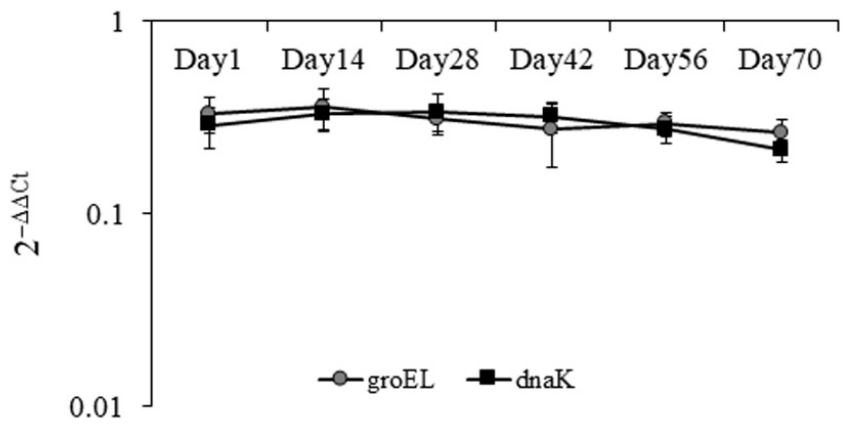

Figure 1. Progress curve of $V$. cholerae culturability and viability during the course of VBNC induction.(a) Culturable cell count was determined for V. cholerae AN59 during the induction of VBNC state at $4{ }^{\circ} \mathrm{C}(\bullet)$ in ASW. Recovery was induced on days 56, 63, 70 and 77 after entry into VBNC state by temperature upshift from $4{ }^{\circ} \mathrm{C}$ to $37^{\circ} \mathrm{C}(\bullet)$. Each bar represents the mean \pm SE of three independent experiments. (b) The relative mRNA expression of transcripts of molecular chaperones ( $\mathbf{\square}) d n a K$ and $(\bullet)$ GroEL were analyzed during the course of VBNC induction as an indicator of cell viability. 
In order to understand the nature of Rpf, spent ASW was subjected either to heat $\left(100{ }^{\circ} \mathrm{C}\right.$ for $\left.10 \mathrm{~min}\right)$ or protease $(100 \mu \mathrm{g} \mathrm{mL}-1$ of proteinase $\mathrm{K})$ treatment. The heat treatment of spent ASW media inhibited the recovery of VBNC cells, whereas the addition of proteinase $\mathrm{K}$ did not. This shows that the Rpfs were heat-sensitive but protease-resistant (Table 1). Interestingly, the addition of proteinase $\mathrm{K}$ at the time of the temperature transition from $4{ }^{\circ} \mathrm{C}$ to $37^{\circ} \mathrm{C}$ led to an extension in the total recovery period from a period of 2 weeks to 5 weeks - i.e., from day70 to day 91 — but not beyond that.

Table 1. Resuscitation-promoting ability of VBNC cells in different media.

\begin{tabular}{cc}
\hline Sample & Recovered cfu $\mathbf{~ m L}^{-1}$ \\
\hline Undiluted VBNC & $6 \times 10^{6}$ \\
\hline 10-fold diluted VBNC in spent ASW media & $4.9 \times 10^{6}$ \\
\hline 10-fold diluted VBNC in heat treated spent ASW media & No recovery \\
\hline 10-fold diluted VBNC in spent ASW supplemented with Proteinase K & $1.58 \times 10^{8}$ \\
\hline
\end{tabular}

\subsection{Effect of Proteinase K during Recovery of $V$. cholerae from VBNC State}

The VBNC cells in spent ASW supplemented with proteinase $\mathrm{K}$ led to an increase to $1.58 \times 10^{8} \mathrm{cfu} \mathrm{mL}{ }^{-1}$ after $32 \mathrm{~h}$ of incubation at $37^{\circ} \mathrm{C}$, whereas resuscitation without proteinase $\mathrm{K}$ led to a recovered cell count of $4.9 \times 10^{6} \mathrm{cfu} \mathrm{mL}^{-1}$. The growth of culturable cells and VBNC cells in ASW media (FM) and proteinase K-supplemented ASW media (FM $+\mathrm{PK})$ was compared to understand the role of proteinase $\mathrm{K}$. We found that $10 \mathrm{cfu} \mathrm{mL}^{-1}$ of CI cells could grow to $1.9 \times 10^{5} \mathrm{cfu} \mathrm{mL}^{-1}$ in FM and $5.2 \times 10^{5} \mathrm{cfu} \mathrm{mL}^{-1}$ in FM $+\mathrm{PK}$ (Figure 2a). The addition of proteinase $\mathrm{K}$ could support only 2.7 -fold more growth in culturable cells, but this difference in growth was not statistically significant. So, proteinase

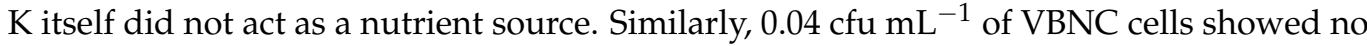
recovery in FM and could attain a recovered cell count up to $1.4 \pm 0.5 \times 10^{7} \mathrm{cfu} \mathrm{mL}^{-1}$ in FM + PK (Figure 2a). Therefore, spent ASW was indispensable for resuscitation to occur in VBNC cells of $V$. cholerae.

Next, the growth of culturable and VBNC cells was compared in spent ASW media (SM) and $\mathrm{SM}+\mathrm{PK}$ to understand the role of proteinase $\mathrm{K}$. The culturable cells could grow to $2.45 \times 10^{6} \mathrm{cfu} \mathrm{mL}^{-1}$ in SM and $4.3 \times 10^{7} \mathrm{cfu} \mathrm{mL}^{-1}$ in SM + PK (Figure 2b). The growth of culturable cells was 13-fold higher in SM than FM and 17.5-fold higher in SM+PK than SM. This indicates that spent ASW media could provide nutrients for growth, and the addition of proteinase $\mathrm{K}$ further enhanced its growth-promoting ability. Likewise, we observed that VBNC cells could grow up to $4.9 \times 10^{6} \mathrm{cfu} \mathrm{mL}^{-1}$ in SM and $1.58 \times 10^{8} \mathrm{cfu} \mathrm{mL}^{-1}$ in $\mathrm{SM}+\mathrm{PK}$ (Figure $2 \mathrm{~b}$ ). The growth of VBNC cells was 32-fold higher in SM+PK than SM. These data further showed that the growth-promoting effect of proteinase $\mathrm{K}$ was higher for stressed VBNC cells compared to culturable cells. 
(a)

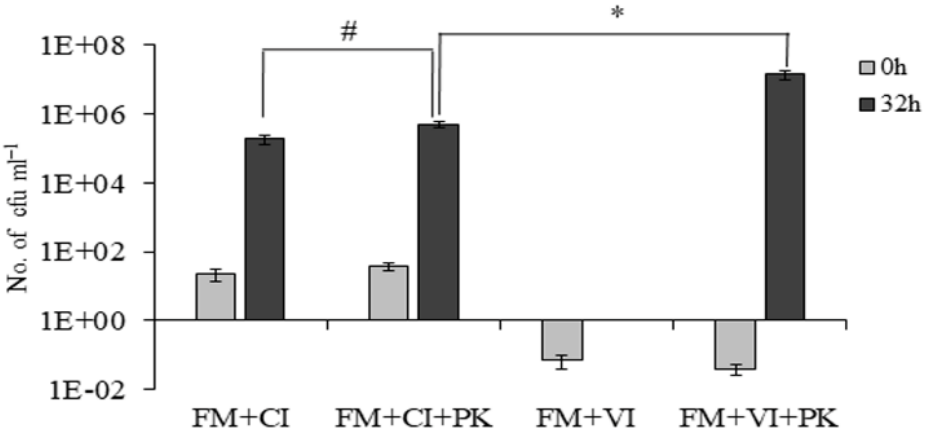

(b)

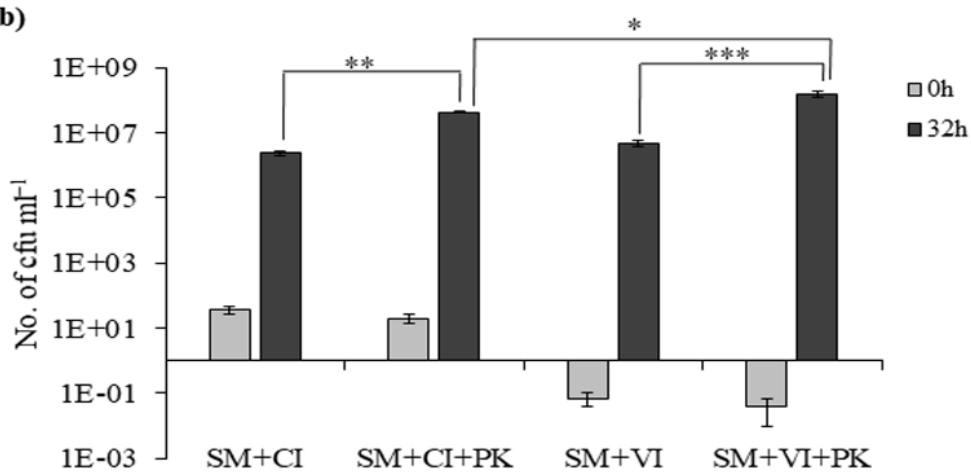

Figure 2. Effect of proteinase $\mathrm{K}$ on VBNC and culturable cells in ASW and spent ASW media. (a) Growth of culturable cells (CI) and recovery of VBNC cells (VI) in ASW media (FM) without or with $100 \mu \mathrm{g} \mathrm{mL}^{-1}$ of proteinase $\mathrm{K}$ (PK); cell count was determined at $0 \mathrm{~h}$ and $32 \mathrm{~h}$. \# represents nonsignificant difference in growth of CI between FM and PK-supplemented FM. Asterisk (*) represents statistically significant difference between the growth of CI and VI in FM + PK $(p<0.05)$. (b) Growth of CI cells and recovery of VI cells in SM (spent ASW media) and SM+PK. Each bar represents the mean \pm SE of three independent experiments. Asterisk $\left({ }^{* *}\right)$ represents statistically significant difference in growth of CI between SM and SM+PK. $(p<0.001)$.Asterisk $\left.{ }^{* * *}\right)$ represents statistically significant difference in growth of VI between SM and SM+PK. $(p<0.02)$. Asterisk $\left({ }^{*}\right)$ represents statistically significant difference in growth between CI and VI in SM+PK $(p<0.05)$.

\subsection{Time-Dependent Recovery of VBNC Cells and Growth of Culturable Cells}

We examined the time-dependent growth of culturable cells in ASW media and proteinase K-supplemented ASW media. The culturable cells could grow from $10 \mathrm{cfu}$ $\mathrm{mL}^{-1}$ to $10^{5} \mathrm{cfu} \mathrm{mL}^{-1}$ in FM as well as in $\mathrm{FM}+\mathrm{PK}$, but the time required to attain that cell number was different. The culturable cells took $12 \mathrm{~h}$ to reach $10^{5} \mathrm{cfu} \mathrm{mL}^{-1}$ in FM + PK with a generation time (gt) of $38.5 \mathrm{~min}$, whereas they needed more than $20 \mathrm{~h}$ in FM with a gt of 86.6 min (Figures 3a and S1a,b). Similarly, the time-dependent growth of VBNC cells in ASW media and proteinase K-supplemented ASW media was examined. As mentioned previously, VBNC cells were not able to grow at all in ASW media. However, 10 cfumL $^{-1}$ of recovered cells was observed in FM + PK after a lag period of approximately $8 \mathrm{~h}$. Then, it could grow to reach $10^{5} \mathrm{cfu} \mathrm{mL} \mathrm{m}^{-1}$ in $6 \mathrm{~h}$, whereas culturable cells took twice this time duration to reach an equivalent number of cells in FM + PK. These recovered cells further grow to $10^{7} \mathrm{cfu} \mathrm{mL} \mathrm{m}^{-1}$ in another $4 \mathrm{~h}$. So, VBNC cells showed maximum growth in a total time duration of $10 \mathrm{~h}$ with a gt of $31.5 \mathrm{~min}$ (Figure $3 \mathrm{~b}$ and Figure S1c). The obtained results showed that the growth rate of culturable cells was increased with proteinase $\mathrm{K}$ but the impact of proteinase $\mathrm{K}$ was higher on the growth rate of recovered cells from the VBNC state. 
(a)

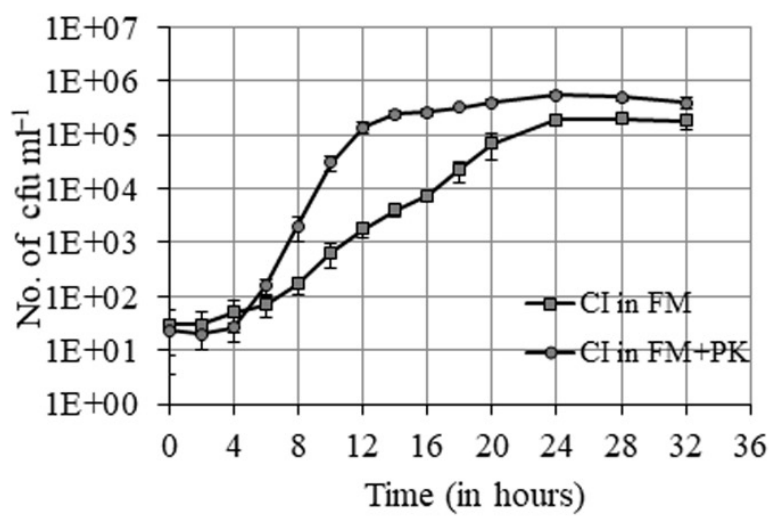

(c)

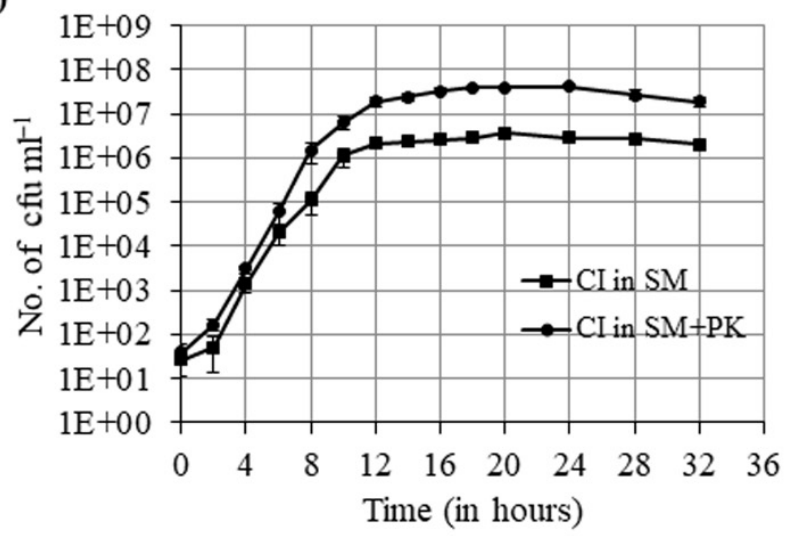

(b)

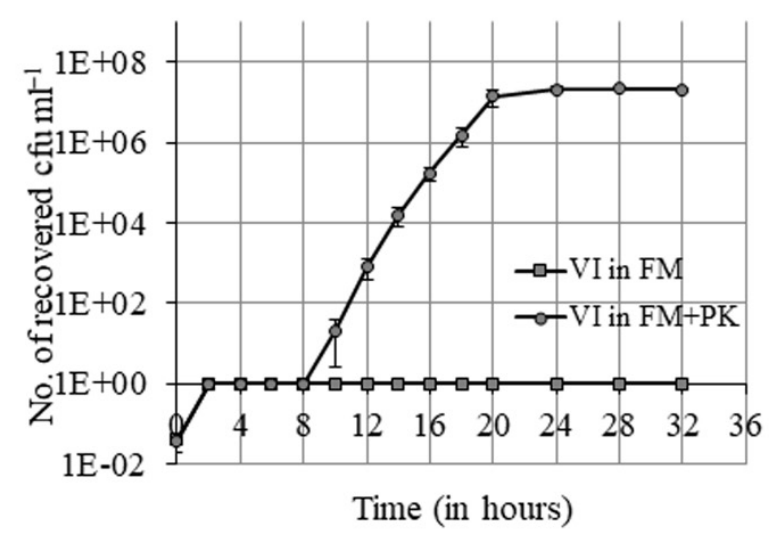

(d)

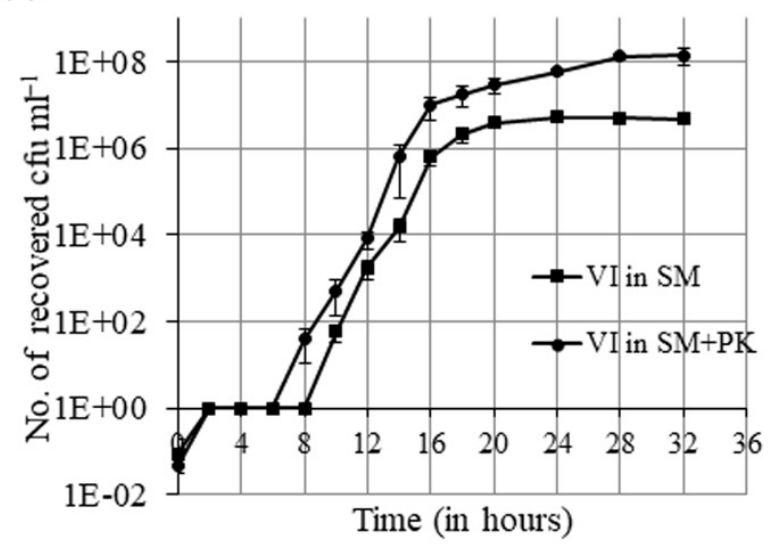

Figure 3. Time-dependent growth curve of culturable cells and resuscitation curve of VBNC cells in ASW (FM), ASW with proteinase $\mathrm{K}(\mathrm{FM}+\mathrm{PK})$, spent ASW (SM) and spent ASW with proteinase K (SM + PK). (a) Growth curve of culturable cells (CI cells) in FM $(\square)$ and FM + PK $(\bullet)$ for $32 \mathrm{~h}$ at $37^{\circ} \mathrm{C}$. The viable cell count was determined by the plate count method at an interval of $2 \mathrm{~h}$ until the end of incubation time. (b) Resuscitation curve of VBNC cells (VI cells) in FM ( $\square$ ) and FM + PK (•)

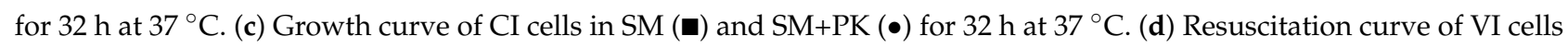
in $\mathrm{SM}(\boldsymbol{\bullet})$ and $\mathrm{SM}+\mathrm{PK}(\bullet)$ for $32 \mathrm{~h}$ at $37^{\circ} \mathrm{C}$. Each data point represents the mean $\pm \mathrm{SE}$ of three independent experiments.

Next, the effect on the growth rate of culturable and VBNC cells was determined by growth curve analysis in spent ASW media and proteinase K-supplemented spent ASW media. The culturable cells took $10 \mathrm{~h}$ to reach $10^{6} \mathrm{cfu} \mathrm{mL} \mathrm{mL}^{-1}$ in SM with a gt of $34.6 \mathrm{~min}$ and $10^{7} \mathrm{cfu} \mathrm{mL} \mathrm{mL}^{-1}$ in SM+PK with a gt of $31.5 \mathrm{~min}$ (Figures $3 \mathrm{c}$ and S2a,b). So, the effect of proteinase $\mathrm{K}$ on the growth rate of culturable cells in spent ASW media was not as prominent as in ASW media. VBNC cells showed an initial lag of $8 \mathrm{~h}$ in spent ASW media before it could reach $10 \mathrm{cfu} \mathrm{mL} \mathrm{m}^{-1}$, and in the next $10 \mathrm{~h}$, it reached $10^{6} \mathrm{cfu} \mathrm{mL}^{-1}$ with a gt of 31.5 min (Figures $3 \mathrm{~d}$ and S2c). This implies that a small population of VBNC cells undergo recovery during the initial non-growth phase and then grow like culturable cells. Moreover, we obtained a detectable number of recovered cells in proteinase K-supplemented spent ASW after $6 \mathrm{~h}$ of lag period, and these recovered cells reached $10^{7} \mathrm{cfu} \mathrm{mL}^{-1}$ with a gt of 26.6 min (Figures $3 \mathrm{~d}$ and S2d). So, the addition of proteinase K could shorten the lag period, resulting in a faster transition from VBNC to recovery states.

\subsection{Effect of Serine Protease on Recovery of V. cholerae from VBNC State Is a General Trait}

Next, the effect of other serine proteases such as trypsin and subtilisin was also tested on the recovery from the VBNC state. We inoculated 0.02 to $0.08 \mathrm{cfu} \mathrm{mL}^{-1}$ of VBNC cells in spent ASW media supplemented with proteinase $K$, subtilisin, trypsin and BSA followed by incubation at $37^{\circ} \mathrm{C}$ for $32 \mathrm{~h}$. The numbers of recovered cells were $6.2 \times 10^{6}$, $1.67 \times 10^{8}, 5.3 \times 10^{8}, 2.8 \times 10^{8}$ and $4.8 \times 10^{6} \mathrm{cfu} \mathrm{mL}^{-1}$ for VBNC only, with proteinase 
K, with subtilisin, with trypsin and with BSA, respectively (Figure 4). So, the effect of proteinase $\mathrm{K}$ on recovery was not an exclusive property; other serine proteases also had similar effects.

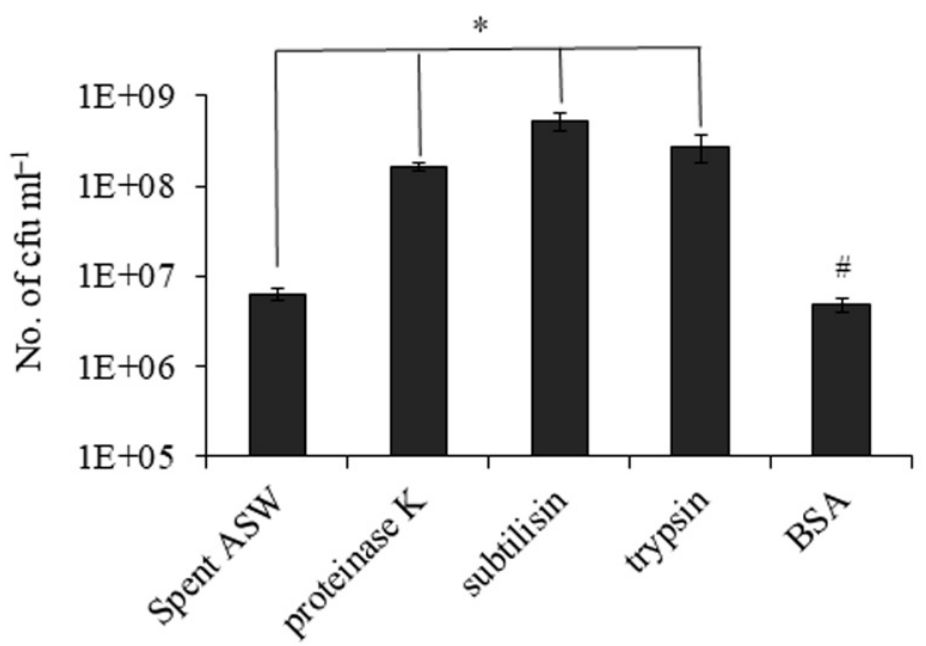

Figure 4. Effect of protease on recovery of $V$. cholerae from the VBNC state is a general trait. Recovery was induced in VBNC cells at $37^{\circ} \mathrm{C}$ in spent ASW media (SM) and heat-treated spent ASW media $(\triangle \mathrm{SM})$ without or with proteinase $\mathrm{K}$, subtilisin, trypsin and BSA. The recovered cell count was determined after $32 \mathrm{~h}$. Asterisk $\left(^{*}\right)$ represents statistically significant difference in growth of VBNC cells with and without proteases in spent ASW media $(p<0.05)$. \# represents non-significant difference in growth of VBNC cells with and without proteases in heat-treated spent ASW media.

\subsection{Growth-Promoting Components of Spent ASW Media}

The components of spent ASW media which might support the growth of VBNC cells were dead bacteria, genomic DNA and proteins. So, we used $10^{7}$ cells of dead bacteria, $10 \mu \mathrm{g} \mathrm{mL} \mathrm{m}^{-1}$ of genomic DNA and $100 \mu \mathrm{g}$ of $\mathrm{mL}^{-1} \mathrm{BSA}$ as nutrient sources and added them to ASW media to check the effect of these components on the growth of culturable cells. The numbers of viable cells obtained after $32 \mathrm{~h}$ in FM, FM with dead cells, FM with genomic DNA, FM with BSA and spent ASW media were $1 \times 10^{5}, 2.4 \times 10^{6}, 4.8 \times 10^{6}, 5.7 \times 10^{5}$ and $3.1 \times 10^{6} \mathrm{cfu} \mathrm{mL}^{-1}$, respectively (Figure 5). This result showed that the addition of dead cells or genomic DNA in nutrient-deficient ASW media could support the growth of culturable cells. However, ASW media supplemented with either dead cells or genomic DNA was incapable of supporting the transformation of VBNC cells into recovered cells. It was only the addition of proteinase K in ASW media that led to recovery in VBNC cells as mentioned earlier. Therefore, protease might play an essential role during the process of resuscitation.

Similarly, this experiment was also performed in the presence of proteinase $\mathrm{K}$. The numbers of viable cells obtained in FM, FM with dead cells, FM with genomic DNA, FM with BSA and spent ASW media were $6 \times 10^{5}, 5.3 \times 10^{7}, 7.5 \times 10^{6}, 6.5 \times 10^{5}$ and $4.3 \times 10^{7} \mathrm{cfu} \mathrm{mL}^{-1}$, respectively (Figure 5). The ASW media supplemented with dead cells and proteinase $\mathrm{K}$ could support a growth rate equivalent to spent ASW media supplemented with proteinase $\mathrm{K}$. This implies that dead cells were present in spent ASW media on which proteinase $\mathrm{K}$ might act to support the high growth of recovered cells. 


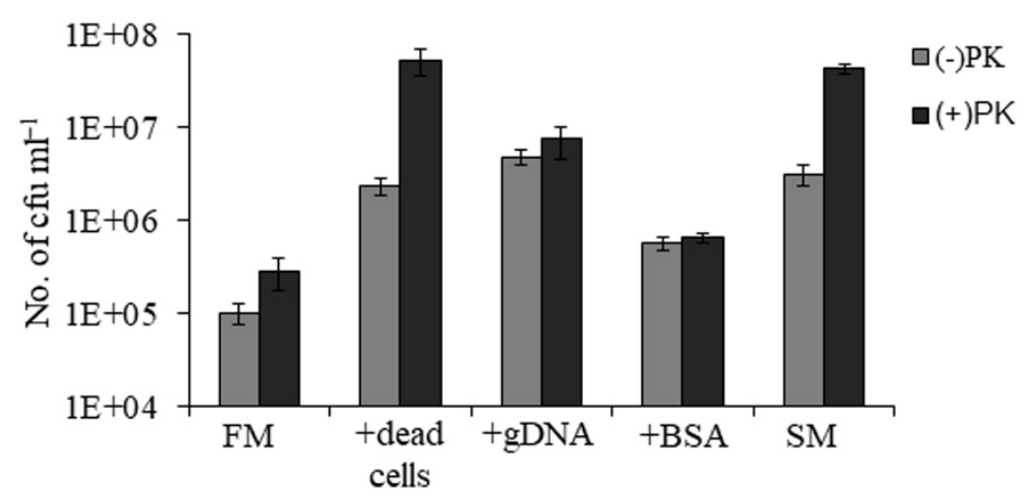

Figure 5. Growth-promoting components of spent ASW media. The growth of culturable cells was checked in ASW media (FM), ASW media with $10^{7}$ cells of dead bacteria (+dead cells), ASW media with $10 \mu \mathrm{g} \mathrm{mL}{ }^{-1}$ genomic DNA (+gDNA), ASW media with 100 of $\mu \mathrm{g} \mathrm{mL}{ }^{-1}$ BSA (+BSA) and spent ASW media (SM). The cell count was determined after $32 \mathrm{~h}$ of incubation and represented as (-) PK. The samples in the presence of proteinase $\mathrm{K}$ are represented as (+) PK.

\subsection{The Recovery State Shows an Increase in Protease Expression}

The effect of proteinase $\mathrm{K}$ on the growth of $\mathrm{V}$. cholerae during recovery prompted us to check the mRNA expression of serine proteases such as vc0099, vc1200, vca0803 and vc1989 (yaeZ) in a time-dependent manner. We found that each of the serine proteases showed a gradual increase in mRNA expression (Figure 6a). This suggests that protease might play a crucial role in the resuscitation of bacteria from a dormant state followed by growth. In another experiment, the protease expression of VBNC cells was checked by skim milk plate assay. We prepared two types of $1 \%$ skim milk plate: one plate was prepared using ASW media, and the second one was prepared using spent ASW media. We found that the VBNC sample showed growth and distinct clear zones only around the well in the skim milk plate constituted of spent ASW media (Figure 6b).

(a)

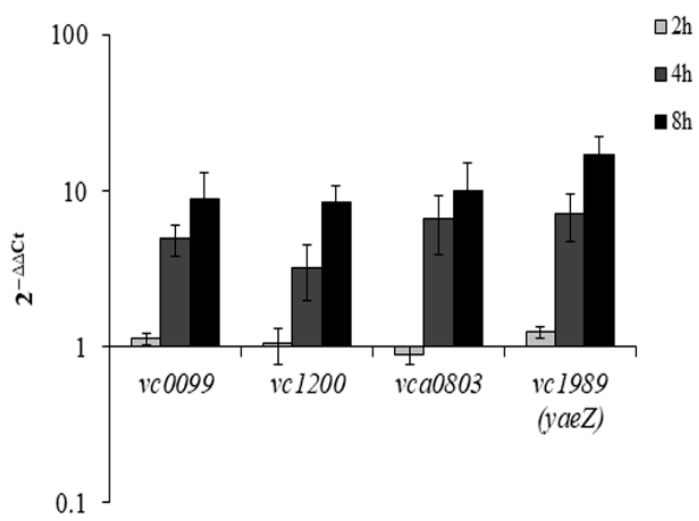

(b)

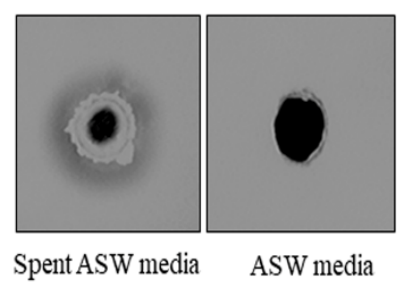

Figure 6. Protease expression at mRNA and protein level during recovery. (a) We checked the mRNA expression of serine proteases such as vc0099, vc1200, vca0803 and vc1989 (yaeZ) in a time-dependent manner $(4 \mathrm{~h}, 8 \mathrm{~h}, 16 \mathrm{~h})$ using dnaK as reference gene. (b) Skim milk plate assay for the detection of protease secretion during recovery from VBNC state. Protease activity on $1 \%$ skim milk plate.

\section{Discussion}

The dormant VBNC state can be transitioned to an active culturable state by several methods such as high temperature, the addition of nutrients, catalase and direct interaction with eukaryotic cells $[3,9,13,14]$. This study showed that spent medium filtered from VBNC microcosm was indispensable for the temperature-dependent recovery of VBNC cells. It was shown in Staphylococcus aureus that spent media could induce recovery in dormant cells, and the resuscitation effect of spent culture was greatly reduced by boiling or the addition 
of $50 \mu \mathrm{g} \mathrm{mL} \mathrm{m}^{-1}$ trypsin [23]. Similarly, it was observed that the heat treatment could destroy the resuscitation-promoting trait of spent media. However, the addition of proteases such as proteinase $\mathrm{K}$, trypsin or subtilisin in spent media showed different effects on $V$. cholerae in the present study. Instead of inhibiting the recovery from the VBNC state, the addition of these serine proteases in spent ASW media led to more efficient recovery compared to the recovery dependent only upon higher temperature. So, whether it was trypsin-like or subtilisin-like protease, the overall effect on recovery was similar. This might be because the substrate on which these serine proteases acted was the same and thus similar results were produced. Therefore, it seems to be a general trait of serine protease to enhance the resuscitation-promoting effect of spent ASW during recovery. Further investigation on other Gram-negative bacteria such as E. coli is required to get a more detailed insight into the role of serine protease during recovery from the VBNC state.

Therefore, in order to understand the effect of proteinase K only, ASW media supplemented with proteinase $\mathrm{K}$ was used instead of spent media for the induction of recovery. Interestingly, in ASW media, which otherwise could not support the recovery of VBNC cells, the presence of proteinase $\mathrm{K}$ made that possible. So, even if we assume that this growth was due to the inclusion of few undetected culturable cells, as also suggested by Ravel et al. [7], it is quite intriguing that VBNC cells could grow up to $10^{7} \mathrm{cfu} \mathrm{mL}^{-1}$ in nutrient-deficient ASW media by the mere addition of proteinase $\mathrm{K}$. The mode of action of proteinase $\mathrm{K}$ was analyzed by comparing the growth of culturable and VBNC cells either in the absence or presence of proteinase $\mathrm{K}$ in a time-dependent growth manner. In the presence of proteinase $\mathrm{K}$, the culturable cells showed a significant increase in the growth rate by reducing the generation time, and the growth rate of VBNC cells was faster with proteinase $\mathrm{K}$ than culturable cells. It was reported that Rpfs of Mycobacteria could stimulate cell division, either by the remodeling of the cell wall, or cell lysis products could initiate an anti-dormancy signaling cascade [26]. It might be speculated that proteinase $\mathrm{K}$ acts in a similar way.

In addition, the comparison of the time-dependent recovery of VBNC cells between spent ASW and proteinase K-supplemented spent ASW media showed that proteinase $\mathrm{K}$ could accelerate the transition from VBNC to recovered cells, and these few recovered cells then grew like culturable cells but with a higher growth rate. We speculate that this increased growth rate of recovered cells was probably due to the availability of an ample amount of pre-digested (by proteinase $\mathrm{K}$ ) cellular components present in spent ASW media. The shortening of the lag phase in the presence of Rpfs was also reported in $S$. aureus [23]. Furthermore, the expression level of serine proteases was examined during the course of recovery. Increased mRNA expression of serine proteases such as $v c 0099$, $v c 1200, v c a 0803$ and $v c 1989$ (yaeZ) was found. A recent study showed that the proteolytic activity of YeaZ promotes resuscitation in VBNC cells of $V$. harveyi, which might be due to the stimulation of the cell division process in the VBNC cells [22]. This study showed evidence that proteinase $\mathrm{K}$ might play a similar role during the resuscitation of VBNC cells of $V$. cholerae. It had also been reported that the addition of YaeZ could result in a higher number of recovered cells and also could induce resuscitation beyond the recovery end point [27]. The nucleotide sequence of $V$. cholerae YaeZ showed 70\% identity with that of $V$. harveyi and $V$. parahaemolyticus. The present study found a similar observation with proteinase $\mathrm{K}$, where the addition of proteinase $\mathrm{K}$ at the time of temperature transition from $4{ }^{\circ} \mathrm{C}$ to $37^{\circ} \mathrm{C}$ led to an extension in the total recovery period from a period of 2 weeks to 5 weeks and a higher number of total recovered cells.

Moreover, genomic DNA and dead bacterial cells present in spent ASW media were identified as good nutrient sources that could be utilized by $V$. cholerae cells for growth $[28,29]$. However, neither the addition of dead cells nor genomic DNA in ASW media could induce resuscitation in VBNC cells. This indicates that their role might be limited to supporting the growth of few recovered cells rather than the induction of resuscitation. Among them, dead cells present in spent ASW seem to be the substrate for proteinase K to support the high growth of recovered cells. A recent study showed that the staphylo- 
coccal proteases aureolysin and staphopain B cleave collagen into peptide fragments that support $S$. aureus growth under nutrient-limited conditions inside a host [30]. So, it can be speculated that proteinase $\mathrm{K}$ might act on the membrane protein of dead bacteria to release peptides, which ultimately support the growth of few recovered cells.

The vast majority of environmental microbes are not capable of growth on laboratory culture media, either due to a lack of a customized culture technique or because of dormancy. So, it is important to develop novel cultivation techniques. Recently, external stimulants have been successfully used to revive bacteria from environmental sources. Su et al. reported that the isolation of biphenyl-degrading bacteria from PCB-contaminated soils was enhanced with the addition of Rpf-containing culture supernatant from M. luteus [31]. In another study, an enrichment media was developed that consisted of $10 \mathrm{mmol} \mathrm{L}^{-1}$ sodium pyruvate in low-nutrient medium, and it was used successfully for the isolation of previously uncultured bacteria from the coastal sediment of China [32]. Similarly, an enrichment media might be formulated for $V$. cholerae using minimal media supplemented with proteinase K. The environmental water samples should be first enriched in this medium, followed by plating on commercially available selective media for Vibrios.

Altogether, this study highlighted the role of protease during recovery from the VBNC state, whether produced by the bacteria or supplemented. The present data project that serine protease could be a possible choice for a resuscitation-promoting factor in $V$. cholerae. Thus, we propose that after a temperature upshift, transition from a VBNC to a recovery or culturable state might occur during the initial lag phase of 6-8 h. The presence of proteinase $\mathrm{K}$ could shorten the length of the lag phase and expedite the transition phase by activating the cell division process. Then, the recovered cells could grow rapidly in nutrient-rich spent ASW media to achieve a higher cell count. Proteinases are found in all domains of life, and one-third of them are serine proteases. In humans, serine proteases are constitutively produced by the pancreas, epithelial cells, immune and mesenchymal cells, whereas serine proteases were mainly studied as virulence factors among bacterial pathogens such as $V$. cholerae. It might be possible that VBNC cells are reactivated and multiplied through the assistance of host and bacterial proteases inside the intestinal environment of humans. Thus, detailed insights into the resuscitation of VBNC cells is essential for the better management of this highly infectious human pathogen which often remains undetected in environmental samples.

Supplementary Materials: The following are available online at https:/ / www.mdpi.com/article / 10.3390/microorganisms9122618/s1, Figure S1. (a), (b) The calculation of generation time (gt) of culturable (CI) cells in ASW media (FM) and proteinase K-supplemented ASW media ( FM + PK). The data points that represent the log phase from the growth curve were used to determine the generation time for CI cells in FM and FM + PK media. All the experiments were performed thrice, and each data point represents the mean \pm SE. (c) The calculation of generation time (gt) of VBNC (VI) cells in FM + PK. The data points which represent the log phase from the growth curve were used to determine the generation time for VI cells in FM + PK media. All the experiments were performed thrice, and each data point represents the mean \pm SE. Figure S2. (a), (b) The calculation of generation time (gt) of culturable (CI) cells in spent ASW media (SM) and proteinase K-supplemented spent ASW media (SM + PK). The data points which represent the log phase from the growth curve were used to determine the generation time for CI cells in SM and SM + PK media. All the experiments were performed thrice, and each data point represents the mean \pm SE. (c), (d) The calculation of generation time (gt) of VBNC (VI) cells in SM and SM + PK. The data points which represent the log phase from the growth curve were used to determine the generation time for VI cells in SM and SM + PK media. All the experiments were performed thrice, and each data point represents the mean $\pm \mathrm{SE}$. Table S1. List of primers used in this study.

Author Contributions: Conceptualization, A.D. and S.-i.M.; funding acquisition, S.-i.M.; methodology, A.D.; writing—original draft preparation, A.D.; writing—review and editing, S.-i.M.; supervision, S.-i.M. All authors have read and agreed to the published version of the manuscript.

Funding: This investigation is supported by the Japan Initiative for Global Research Network on Infectious Diseases (J-GRID; JP20wm0125004) from Ministry of Education, Culture, Sport, Science and 
Technology in Japan (MEXT) and Japan Agency for Medical Research and Development (AMED). The funders had no role in study design, data collection and analysis, or preparation of the manuscript.

Conflicts of Interest: The authors declare that there are no conflicts of interest.

$\begin{array}{ll}\text { Abbreviations } \\ \text { VBNC } & \text { viable but non-culturable } \\ \text { ASW } & \text { artificial sea water } \\ \text { FM } & \text { ASW media } \\ \text { SM } & \text { spent ASW media } \\ \text { PK } & \text { proteinase K } \\ \text { FM + PK } & \text { proteinase K-supplemented ASW media }\end{array}$

\section{References}

1. Zhao, X.; Zhong, J.; Wei, C.; Lin, C.W.; Ding, T. Current Perspectives on Viable but Non-culturable State in Foodborne Pathogens. Front. Microbiol. 2017, 8, 580. [CrossRef]

2. Lattos, A.; Bitchava, K.; Giantsis, I.A.; Theodorou, J.A.; Batargias, C.; Michaelidis, B. The Implication of Vibrio Bacteria in the Winter Mortalities of the Critically Endangered Pinna nobilis. Microorganisms 2021, 9, 922. [CrossRef]

3. Debnath, A.; Mizuno, T.; Miyoshi, S.I. Comparative proteomic analysis to characterize temperature-induced viable but nonculturable and resuscitation states in Vibrio cholerae. Microbiology (Reading) 2019, 165, 737-746. [CrossRef] [PubMed]

4. Coutard, F.; Crassous, P.; Droguet, M.; Gobin, E.; Colwell, R.R.; Pommepuy, M.; Hervio-Health, D. Recovery in culture of viable but nonculturable Vibrio parahaemolyticus: Regrowth or resuscitation? ISME J. 2007, 1, 111-120. [CrossRef]

5. Nilsson, L.; Oliver, J.D.; Kjelleberg, S. Resuscitation of Vibrio vulnificus from the viable but nonculturable state. J. Bacterial. 1991, 173, 5054-5069. [CrossRef] [PubMed]

6. Whitesides, M.D.; Oliver, J.D. Resuscitation of Vibrio vulnificus from the viable but non culturable state. Appl. Environ. Microbiol. 1997, 63, 1002-1005. [CrossRef]

7. Ravel, J.; Knight, I.T.; Monahan, C.E.; Hill, R.T.; Colwell, R.R. Temperature-induced recovery of Vibrio cholerae from the viable but nonculturable state: Growth or resuscitation? Microbiology 1995, 141, 377-383. [CrossRef]

8. Liu, Y.; Wang, C.; Tyrrell, G.; Hrudey, S.E.; Li, X.F. Induction of Escherichia coli O157:H7 into the viable but non-culturable state by chloraminated water and river water, and subsequent resuscitation. Environ. Microbiol. Rep. 2009, 1, 155-161. [CrossRef] [PubMed]

9. Pinto, D.; Almeida, V.; Almeida Santos, M.; Chambel, L. Resuscitation of Escherichia coli VBNC cells depends on a variety of environmental or chemical stimuli. J. Appl. Microbiol. 2011, 110, 1601-1611. [CrossRef]

10. Morishige, Y.; Fujimori, K.; Amano, F. Differential resuscitative effect of pyruvate and its analogues on VBNC (viable but non-culturable) Salmonella. Microbes. Environ. 2013, 28, 180-186. [CrossRef]

11. Zeng, B.; Zhao, G.; Cao, X.; Yang, Z.; Wang, C.; Hou, L. Formation and resuscitation of viable but nonculturable Salmonella typhi. Biomed. Res. Int. 2013, 907170.

12. Morishige, Y.; Koike, A.; Tamura-Ueyama, A.; Amano, F. Induction of Viable but Non culturable Salmonella in Exponentially Grown Cells by Exposure to a Low-Humidity Environment and Their Resuscitation by Catalase. J. Food Prot. 2017, 80, 288-294. [CrossRef] [PubMed]

13. Senoh, M.; Hamabata, T.; Takeda, Y. A factor converting viable but nonculturable Vibrio cholerae to a culturable state in eukaryotic cells is a human catalase. Microbiologyopen 2015, 4, 589-596. [CrossRef] [PubMed]

14. Senoh, M.; Ghosh-Banerjee, J.; Ramamurthy, T.; Colwell, R.R.; Miyoshi, S.; Nair, G.B.; Takeda, Y. Conversion of viable but nonculturable enteric bacteria to culturable by co-culture with eukaryotic cells. Microbiol. Immunol. 2012, 56, 342-345. [CrossRef]

15. Cappelier, J.M.; Besnard, V.; Roche, S.M.; Velge, P.; Federighi, M. Avirulent viable but non culturable cells of Listeria monocytogenes need the presence of an embryo to be recovered in egg yolk and regain virulence after recovery. Vet. Res. 2007, 38, 573-583. [CrossRef]

16. Guillou, S.; Leguerinel, I.; Garrec, N.; Renard, M.A.; Cappelier, J.M.; Federighi, M. Survival of Campylobacter jejuni in mineral bottled water according to difference in mineral content: Application of the Weibull model. Water Res. 2008, 42, 2213-2219. [CrossRef] [PubMed]

17. Kana, B.D.; Mizrahi, V. Resuscitation-promoting factors as lytic enzymes for bacterial growth and signaling. FEMS Immunol. Med. Microbiol. 2010, 58, 39-50. [CrossRef] [PubMed]

18. Rosser, A.; Stover, C.; Pareek, M.; Mukamolova, G.V. Resuscitation-promoting factors are important determinants of the pathophysiology in Mycobacterium tuberculosis infection. Crit. Rev. Microbiol. 2017, 43, 621-630. [CrossRef]

19. Panutdaporn, N.; Kawamoto, K.; Asakura, H.; Makino, S.I. Resuscitation of the viable but non-culturable state of Salmonella enterica serovar Oranienburg by recombinant resuscitation-promoting factor derived from Salmonella Typhimurium strain LT2. Int. J. Food Microbiol. 2006, 106, 241-247. [CrossRef] 
20. Handford, J.I.; Ize, B.; Buchanan, G.; Butland, G.P.; Greenblatt, J.; Emili, A.; Palmer, T. Conserved network of proteins essential for bacterial viability. J. Bacteriol. 2009, 191, 4732-4749. [CrossRef]

21. Aydin, I.; Saijo-Hamano, Y.; Namba, K.; Thomas, C.; Roujeinikova, A. Structural analysis of the essential resuscitation promoting factor YeaZ suggests amechanism of nucleotide regulation through dimer reorganization. PLoS ONE 2011, 6, e23245. [CrossRef]

22. Zhao, R.; Chen, J.; Wang, Y.; Li, Y.; Kong, X.; Han, Y. Proteolytic activity of Vibrio harveyi YeaZ is related with resuscitation on the viable but non-culturable state. Lett. Appl. Microbiol. 2020, 71, 126-133. [CrossRef]

23. Pascoe, B.; Dams, L.; Wilkinson, T.S.; Harris, L.G.; Bodger, O.; Mack, D.; Davies, A.P. Dormant cells of Staphylococcus aureus are resuscitated by spent culture supernatant. PLoS ONE 2014, 9, e85998. [CrossRef]

24. Asakura, H.; Ishiwa, A.; Arakawa, E.; Makino, S.; Okada, Y.; Yamamoto, S.; Igimi, S. Gene expression profile of Vibrio cholerae in the cold-stress induced viable but non-culturable state. Environ. Microbiol. 2006, 9, 869-879. [CrossRef] [PubMed]

25. Wong, H.C.; Wang, P. Induction of viable but nonculturable state in Vibrio parahaemolyticus and its susceptibility to environmental stresses. J. Appl. Microbiol. 2004, 96, 359-366. [CrossRef] [PubMed]

26. Keep, N.H.; Ward, J.M.; Cohen-Gonsaud, M.; Henderson, B. Wake up! Peptidoglycan lysis and bacterial non-growth states. Trends Microbiol. 2006, 14, 271-276. [CrossRef]

27. Li, Y.; Chen, J.; Zhao, M.; Yang, Z.; Yue, L.; Zhang, X. Promoting resuscitation of viable but nonculturable cells of Vibrio harveyi by a resuscitation-promoting factor-like protein YeaZ. J. Appl. Microbiol. 2017, 122, 338-346. [CrossRef]

28. McDonough, E.; Kamp, H.; Camilli, A. Vibrio cholerae phosphatases required for the utilization of nucleotides and extracellular DNA as phosphate sources. Mol. Microbiol. 2016, 99, 453-469. [CrossRef]

29. Takano, S.; Pawlowska, B.J.; Gudelj, I.; Yomo, T.; Tsuru, S. Density-Dependent Recycling Promotes the Long-Term Survival of Bacterial Populations during Periods of Starvation. mBio 2017, 8, e2336-16. [CrossRef] [PubMed]

30. Lehman, M.K.; Nuxoll, A.S.; Yamada, K.J.; Kielian, T.; Carson, S.D.; Fey, P.D. Protease-mediated growth of Staphylococcus aureus on host proteins is opp3 dependent. mBio 2019, 10, e2553-18. [CrossRef]

31. Su, X.; Shen, H.; Yao, X.; Ding, L.; Yu, C.; Shen, C. A novel approach to stimulate the biphenyl-degrading potential of bacterial community from PCBs-contaminated soil of e-waste recycling sites. Bioresour. Technol. 2013, 146, 27-34. [CrossRef] [PubMed]

32. Mu, D.-S.; Liang, Q.-Y.; Wang, X.-M.; Lu, D.-C.; Shi, M.-J.; Chen, G.-J.; Du, Z.-J. Metatranscriptomic and comparative genomic insights into resuscitation mechanisms during enrichment culturing. Microbiome 2018, 6, 230. [CrossRef] [PubMed] 